\title{
Determination of Color and Odor Preferences of Honey Bees (Apis Mellifera L.)
}

\author{
Yaşar Erdoğan ${ }^{1, a, *}$, Kani Yavuz ${ }^{2, b}$ \\ ${ }^{1}$ Department of Veterinary Medicine, Demirözü Vocational High School, Bayburt University, 69000 Bayburt, Turkey \\ ${ }^{2}$ Provincial Directorate of Agriculture, Forestry and Livestock, Livestock Branch, 69000 Bayburt, Turkey \\ *Corresponding author \\ A R T I C L I N F O A B S T R A C T \\ Research Article \\ This study was carried out in the beekeeping research area of Bayburt University in order to \\ determine the effect of odor and color on plant preference of honeybees in 2021. The experimental \\ setup was established at a distance of 200 meters from the apiary where 80 Caucasian bees (Apis \\ mellifera caucasica) colonies are located. As a result of the study, the most preferred feeders were \\ Received : 06/12/2021 \\ Accepted : 03/02/2022 \\ the control group (pure sucrose syrup) (9.81 pieces), and the least preferred feeders were the rose- \\ scent group (2.58). The effect of odor on honeybees' feed preferences varied according to months. \\ Considering the effect of months on honeybees' visits to their feeders, the most visited feeders were \\ Melissa (6.8) in June, control (11.69) in July, and control (14.58) in August. The highest number of \\ feeder visits by honeybees was in August (9.24), and the lowest (2.89) in June. Considering the \\ color preferences of honeybees, the most visited forage color was blue (5.98) and the least red was \\ Keywords: \\ Honey bee \\ Apis mellifera \\ Odor preference \\ 4.89. The effect of colors on the feed preferences of honeybees also varied according to the months. \\ The highest visitor bee average was found in the blue colored feeder (4.53) in June, the green \\ colored feeder (7.24) in July, and the yellow and blue colored feeders (7.29) in August.
}

Color preference

Beekeeping

\section{Introduction}

Flowers need pollinator insects for pollination, and pollinator insects need flowers for feeding (Cengiz and Tunç, 2021; Ghosh et al., 2020). The most important pollinator insects are honeybees. It is known that among more than 250 thousand species of flowering plants distributed in the world, approximately 20 thousand of them are visited by honey bees (Kaufman, 1989). Honeybees do not randomly visit different types of flowers. Honeybees have a behavior called flower constancy, and they visit a single or a small number of plant species during each flight in search of food. (Chittka et al., 1999; Waser, 1986).

Honey bees use the odors of flowers to search for food sources and locate them (Frisch, 1919). Forager bees learn the odor of nectar and pollen on their first flight and use this to re-find their feeding place on their next flight. They can keep these learned odors in their memory for a few days (Beekman, 2005; Frisch and Frisch, 1967). The bees inside the hive can also learn the odors that permeate the honeybees returning without collecting nectar and pollen. Smell and memorization are useful not only in identifying flower types but also in organizing the duties of forager bees (Farina et al., 2005; Frisch and Frisch, 1967; Grüter et al., 2006; Wenner et al., 1969).

Bees returning from a flight to collect nectar or pollen from the field not only provide information about the location and type of the source but also increase their ability to find the feeding area by teaching the flower clues such as shape, color, and odor. The odors used in recognizing flowers are easily learned by bees and play an important role in recognizing food sources, especially at close ranges (Menzel and Müller, 1996). Floral odors contain mixtures of many volatile compounds (Knudsen et al., 1993). Honeybees have the ability to easily distinguish the odors of all plants from each other (Pelz et al., 1997; Smith, 1993).

The preference of nectar and pollen sources of honeybees may differ according to plant species (Danka and Rinderer, 1986; Dietz, 1992). This situation can also vary depending on the proximity, quantity, quality and variety of the nectar and pollen source (Cengiz, 2018; Genç and Dodoloğlu, 2002). In addition, it is known that the 
color of the honeybees is effective in plant selection (Menzel et al., 1991; Menzel and Shmida, 1993).

In a study, it was determined that honey bees (Apis mellifera L.) prefer violet to blue and blue to yellow (Giurfa et al., 1995).

However, a study of the same species in Australia showed that bees showed a significant preference for yellow rather than blue (Guez et al., 2012; Guez et al., 2010).

The aim of this study is to determine the color and odor preferences of honeybees.

\section{Material and Method}

The study was carried out in Bayburt University Demirözü vocational high school beekeeping practice area in 2021. In the study, sucrose syrup consisting of 1/1 sugar water mixture was used. In the experiment, petri dishes painted with acrylic paints in seven different colors, white, red, green, yellow, lily, blue and orange, were used to determine the color preferences of honeybees. The study was carried out at a distance of 200 meters from the apiary where 80 Caucasian bee (Apis mellifera caucasica) colonies are located.

Petri dishes were used as feeders, and these feeders were placed on a stand $50 \mathrm{~cm}$ high from the ground (Figure 1). Before starting the experiment, colorless transparent glass feeders were used to accustom the honeybees to the area and the feeders. When the experiment started, a total of 21 feeders, three for each color, were randomly placed on the table (Figure 1).

\section{Experimental Procedure}

\section{Color Preference}

One day before the experiment, transparent feeders filled with syrup containing $1 / 1$ water/sucrose were placed on the $50 \mathrm{~cm}$ high table and the bees were accustomed to the feeding area. The experiment started on the second day. 21 glass feeders, which are painted with acrylic paint on the outside and contain 50cc syrup, are placed on the table (Table 2). The distance between the feeders is set at $40 \mathrm{~cm}$.

The reason why we chose this distance is that in a study conducted by Huber (1994), honey bees concluded that they can successfully distinguish forages at a distance of $40 \mathrm{~cm}$. The positions of the feeders were determined by chance at the beginning of each experiment. The experiment was terminated when the syrups in the feeders were finished. The study was carried out in May, July and September. It was repeated three times a month with an interval of one week. The experiment was carried out between 10 and 12 o'clock.

\section{Odor Preference}

Four drops of natural essential oil have been added to the syrup in the feeders. A number was determined for each essence and these numbers were written on the feeder with a pen. Three feeders were created for each odor and these feeders were placed at a distance of $40 \mathrm{~cm}$ from each other (Figure 1). At the beginning of each experiment, the locations of the feeders were determined by chance. The experiment was carried out in May, July and September. In each month, it was repeated three times with an interval of one week. We conducted the experiment between 10 and 12 o'clock.
Table 1. Number of bees visiting feeders by color, odors and months.

\begin{tabular}{l|cc}
\hline \multirow{5}{*}{ Odors } & Rose & Average number of honeybees \\
\cline { 2 - 3 } & Jasmine & $7.6667^{\mathrm{de}}$ \\
& Silverberry & $4.9704^{\mathrm{c}}$ \\
& rose & $2.5778^{\mathrm{a}}$ \\
& Melissa & $7.2296^{\mathrm{d}}$ \\
& Mint & $8.1333^{\mathrm{e}}$ \\
& Thyme & $3.7630^{\mathrm{b}}$ \\
& Control & $9.8083^{\mathrm{f}}$ \\
\hline \multirow{5}{*}{ Months } & June & $2.8921^{\mathrm{a}}$ \\
& July & $6.5587^{\mathrm{b}}$ \\
& August & $9.2381^{\mathrm{c}}$ \\
\hline \multirow{5}{*}{ Colors } & Red & $4.8963^{\mathrm{a}}$ \\
& Green & $5.5407^{\mathrm{a}}$ \\
& Yellow & $5.1407^{\mathrm{a}}$ \\
& Orange & $5.1259^{\mathrm{a}}$ \\
& Lily & $5.2074^{\mathrm{a}}$ \\
& Blue & $5.9778^{\mathrm{a}}$ \\
& White & $5.0000^{\mathrm{a}}$ \\
\hline \multirow{3}{*}{ Months } & June & $3.8317^{\mathrm{a}}$ \\
& July & $6.0540^{\mathrm{b}}$ \\
& August & $5.9238^{\mathrm{b}}$ \\
\hline
\end{tabular}

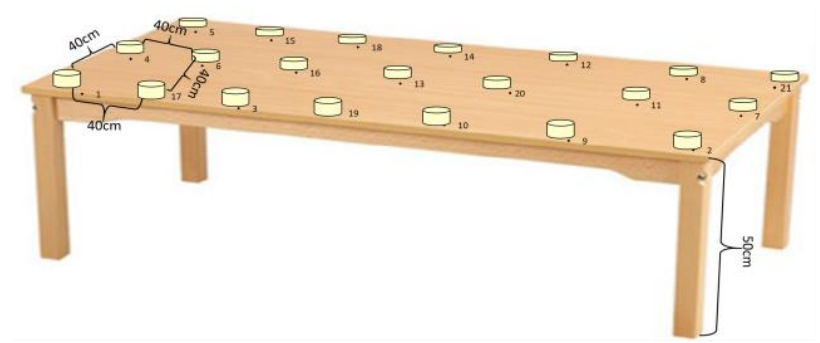

Figure 1. The experimental setup designed according to odor.

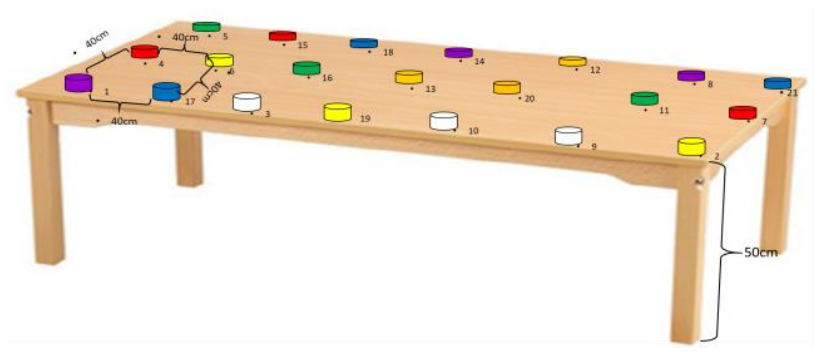

Figure 2. The experimental setup designed according to color.

\section{HONEYBEES}

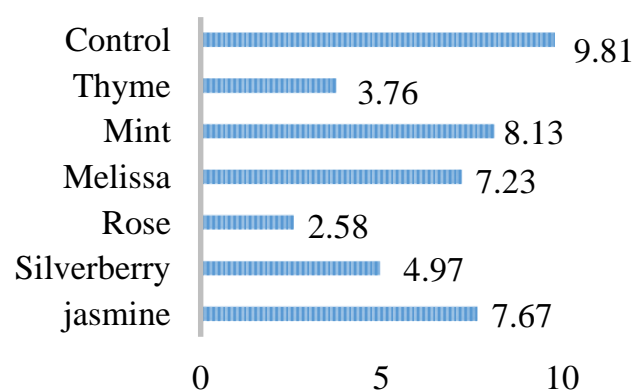

Figure 3. Average number of honeybees visiting feeders according to their odors. 

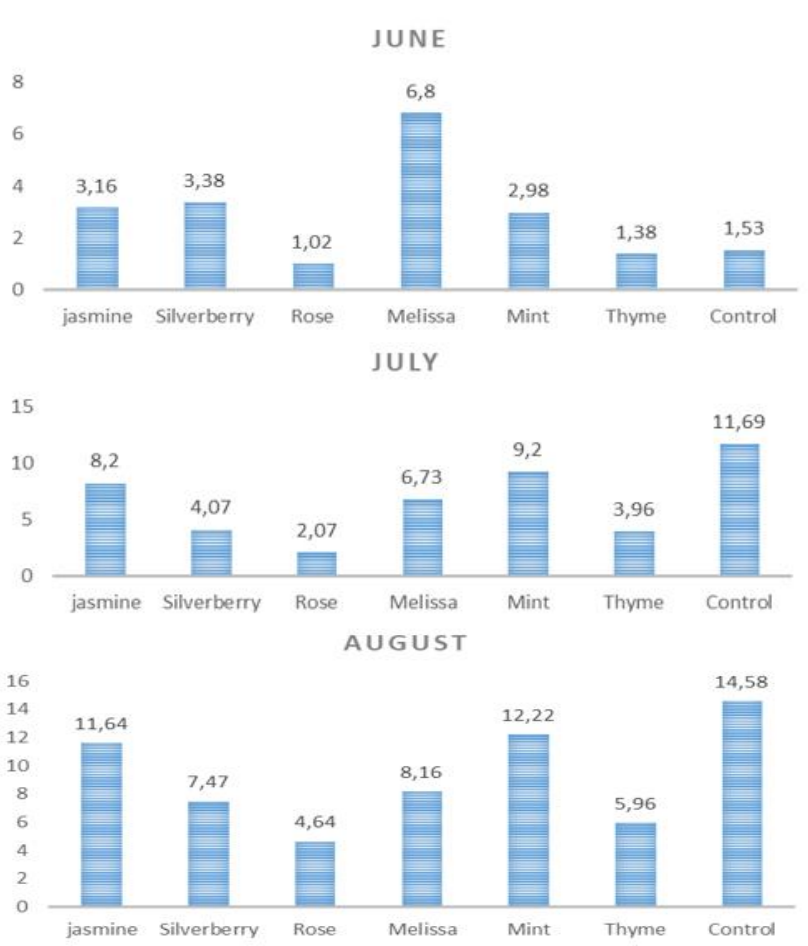

Figure 4. The average number of honeybees visiting the feeders according to their odors in the months of the experiment.

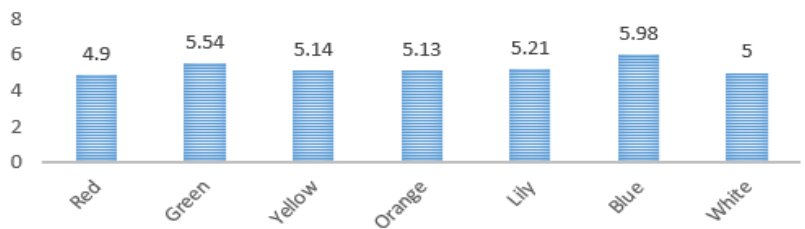

Figure 5. Average number of honeybees visiting feeders according to their colors.
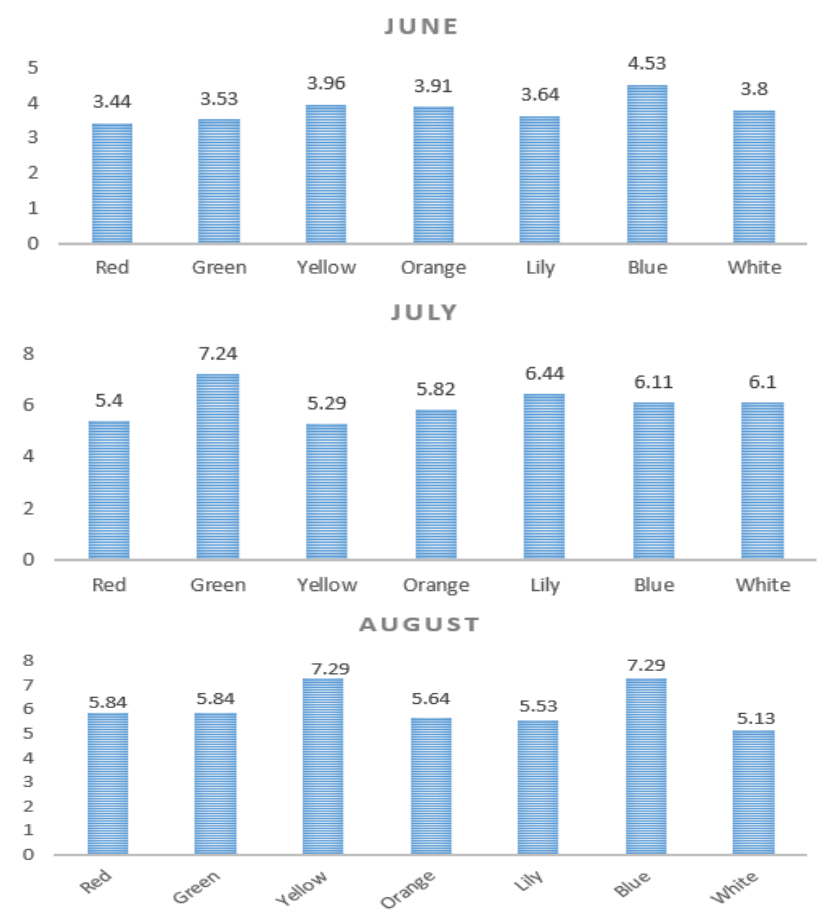

Figure 5. The average number of honeybees visiting the feeders according to their odors in the months of the experiment.

\section{Forager Landing}

The bees placed in the feeders were counted at 30second intervals for 30 minutes. The feeders were moved randomly every 2 minutes to eliminate the possibility of possible location preferences of the honey bees (Guez et al., 2017).

\section{Statistical Analysis}

All data were analyzed using ANOVA (IBM SPSS 22 Statistics software). The significance level was taken as $\mathrm{P}<0.05$ in all analyses. Newman-Keuls post hoc test was used to compare the means.

\section{Results and Discussion}

At the beginning of the study, it was observed that honeybees wandered around the feeders but did not land. As time progressed, honeybees began to be placed in feeders and to take syrup.

When we look at the effect of odor on the feed preferences of honey bees, the most preferred feeder belonged to the control (9.81) group, while the least effective was the feeder with rose odor (2.58) (Table 1). The effect of the odor on the feed preferences of honeybees varied according to the months. In June, the highest average Melissa (6.8), the lowest average rose (1.02), while in July the highest control (11.69), the lowest (2.07) rose (Figure 3). Looking at the August data, the highest average was control (14.58) and the lowest average was rose (4.64) (Figure 4). The highest number of feeder visits by honeybees was in August (9.24), and the lowest was in June with a rate of 2.89 (Table 1).

When we look at the preferences of the colors by the honeybees, the feeder color visited by the bees at the highest rate was blue (5.98), and the lowest bee visitation rate was 4.89 for the color red (Table 1). Considering the color preferences of honeybees by months, the highest preference was in July (6.05), and the lowest preference was in June (3.83) (Table 1).

The effect of colors on the feed preferences of honeybees varied according to the months. In June, the highest average was blue (4.53) and the lowest average was red (3.44) (Figure 5), while in July it was the highest green (7.24) and lowest yellow (5.29) (Figure 5). In August, the highest averages were 7.29 in yellow and blue, and the lowest in white (5.13) (Figure 5). In this study, in which the effect of colors on the forage preferences of honey bees was measured, the most intense bee visits were in July (5.92) and the lowest visits were in June with 3.83 (Table 1).

According to the results of the analysis of variance applied to the average number of honey bees visiting the feeders, all of the feeders with fragrance added were in different groups and the feeders of different colors were in the same group $(\mathrm{P}<0.05)$ (Table1).

The color preferences of forager bees are one of the most effective methods of finding flowers while traveling around the field to collect nectar. The nectar ratio of the flowers, which honeybees visit most, is higher than the others (Giurfa et al., 1995). In a study on bamboo bees, it was revealed that colors are of great importance in finding the nectar source, but color preferences vary from colony to colony (Raine and Chittka, 2007).

In this study, it has been revealed that honeybees prefer the blue color more (5.9778). This result is compatible with 
previous studies (Giurfa et al., 1995). In addition, in a study conducted in Australia (Guez et al., 2012; Guez et al., 2010), it was concluded that Apis mellifera prefer yellow color more. In our study, the yellow color (5.14) was the fourth most preferred color (Figure 4). In another study, it was determined that stingless bees prefer green color (Dyer et al., 2016) (Dyer et al., 2016). In these color preferences, it is thought that the dominant plant density in the region where the apiary is located may also change depending on the color.

In the studies, it has been determined that it is possible to affect the color perception of bees in various physiological factors (Giurfa et al., 1997; Giurfa et al., 1996; Kemp et al., 2015; Wyszecki and Stiles, 1982). Color preferences in insects that visit flowers are a reasonable way of finding them (Giurfa et al., 1995; Raine and Chittka, 2007). The world of honeybees consists of scents. Bees do all their activities inside and outside the hive with the help of scents.

In nature, the pollen, nectar, leaves, and roots of plants emit their own unique odors. Flowers produce scents from glands called osmophores to attract honeybees (Effmert et al., 2006). Honeybees can memorize these scents and do not forget them for days (Beekman, 2005)

Previously, many studies have been conducted on the effects of odors on the physiological and behavioral characteristics of honeybees (Deisig et al., 2006; Deisig et al., 2002; Galizia and Menzel, 2000; Joerges et al., 1997). Some studies have found that honey bees are more responsive to some odors than others (Laloi et al., 2000; Le Metayer et al., 1997; Pham-Delegue et al., 1993; Wadhams et al., 1994). Again, in previous studies, some results have been reported that honeybees can learn odors (Farina et al., 2005; Frisch and Frisch, 1967; Wenner et al., 1969).

In a study conducted by Lindauer (1949), rose essential oil was added to the first sugar syrup and holly essential oil was added to the second sugar syrup and presented to the preference of bees. As a result of the study, it was determined that the number of honey bees coming to the rose-scented syrup was much higher, and at the same time, these bees danced much more eagerly when they returned to their hives.

In our study, according to the results we obtained, the highest bee visits were made to plain sugar syrup. The lowest visits were for sugar syrup with rose essence. It is thought that the unique smell of sucrose syrup is more attractive to honey bees as the reason for this.

\section{References}

Beekman M. 2005. How Long Will Honey Bees (Apis Mellifera L.) Be Stimulated by Scent to Revisit Past-Profitable Forage Sites? Journal of Comparative Physiology A 191: 1115-1120.

Cengiz MM. 2018. Arıcılık ve Organik Bal Üretimi İçin Narman (Erzurum, Türkiye) Doğal Meralarında Ballı Bitki Potansiyeli. Gümüşhane Üniversitesi Fen Bilimleri Enstitüsü Dergisi 8: 358-364.

Cengiz MM, Tunç MA. 2021. Distribution of Some Important Honey Plants Visited by Honey Bees for Feeding Purposes in Narman (Erzurum, Turkey) Natural Pasture Vegetation. GSC Biological Pharmaceutical Sciences 17: 217-222.

Chittka L, Thomson JD, Waser NM. 1999. Flower Constancy, Insect Psychology, and Plant Evolution. Naturwissenschaften 86: 361-377.
Danka RG, Rinderer TE. 1986. Africanized Bees and Pollination. American Bee Journal 126: 680-682.

Deisig N, Giurfa M, Lachnit H, Sandoz JC. 2006. Neural Representation of Olfactory Mixtures in the Honeybee Antennal Lobe. European Journal of neuroscience 24: 11611174 .

Deisig N, Lachnit H, Giurfa M. 2002. The Effect of Similarity between Elemental Stimuli and Compounds in Olfactory Patterning Discriminations. Learning and Memory 9: 112121.

Dietz A. 1992. Honey Bees of the World. 10.

Dyer AG, Boyd-Gerny S, Shrestha M, Lunau K, Garcia JE, Koethe S, Wong BBJJoCPA. 2016. Innate Colour Preferences of the Australian Native Stingless Bee Tetragonula Carbonaria Sm. 202: 603-613.

Effmert U, Buss D, Rohrbeck D, Piechulla B. 2006. Localization of the Synthesis and Emission of Scent Compounds within the Flower. Biology of floral scent: 105-124.

Farina WM, Grüter C, Díaz PC. 2005. Social Learning of Floral Odours inside the Honeybee Hive. Proceedings of the Royal Society B: Biological Sciences 272: 1923-1928.

Frisch Kv. 1919. ÜBer Den Geruchsinn Der Biene Und Seine BlüTenbiologische Bedeutung.

Frisch Kv, Frisch Kv. 1967. Dance Language and Orientation of Bees.

Galizia CG, Menzel R. 2000. Odour Perception in Honeybees: Coding Information in Glomerular Patterns. Current opinion in neurobiology 10: 504-510.

Genç F, Dodoloğlu AJAÜZFDY. 2002. Arıcılığın Temel Esasları. 338.

Ghosh S, Jeon H, Jung CJJoE, Environment. 2020. Foraging Behaviour and Preference of Pollen Sources by Honey Bee (Apis Mellifera) Relative to Protein Contents. 44: 1-7.

Giurfa M, Nunez J, Chittka L, Menzel R. 1995. Colour Preferences of Flower-Naive Honeybees. Journal of Comparative Physiology A 177: 247-259.

Giurfa M, Vorobyev M, Brandt R, Posner B, Menzel RJJoCPA. 1997. Discrimination of Coloured Stimuli by Honeybees: Alternative Use of Achromatic and Chromatic Signals. 180: 235-243.

Giurfa M, Vorobyev M, Kevan P, Menzel RJJoCPA. 1996. Detection of Coloured Stimuli by Honeybees: Minimum Visual Angles and Receptor Specific Contrasts. 178: 699-709.

Grüter C, Acosta LE, Farina WMJBE, Sociobiology. 2006. Propagation of Olfactory Information within the Honeybee Hive. 60: 707-715.

Guez D, Subias L, Griffin ASJBI. 2017. Colour and Shape Preferences of Apis Cerana (Java Genotype) in Australia. 70: 267-272.

Guez D, Zhu H, Zhang SW. 2012. Improved Cholinergic Transmission Is Detrimental to Behavioural Plasticity in Honeybees (Apis Mellifera). Biology 1: 508-520.

Guez D, Zhu H, Zhang SW, Srinivasan M. 2010. Enhanced Cholinergic Transmission Promotes Recall in Honeybees. Journal of Insect Physiology 56: 1341-1348.

Huber B, Couvillon P, Bitterman M. 1994. Place and Position Learning in Honeybees (Apis Mellifera). Journal of Comparative Psychology 108: 213.

Joerges J, Küttner A, Galizia CG, Menzel R. 1997. Representations of Odours and Odour Mixtures Visualized in the Honeybee Brain. Nature 387: 285-288.

Kaufman PB. 1989. Plants: Their Biology and Importance. Harpercollins College Division.

Kemp DJ, Herberstein ME, Fleishman LJ, Endler JA, Bennett AT, Dyer AG, Hart NS, Marshall J, Whiting MJJTAN. 2015. An Integrative Framework for the Appraisal of Coloration in Nature. 185: 705-724.

Knudsen JT, Tollsten L, Bergström LGJP. 1993. Floral Scentsa Checklist of Volatile Compounds Isolated by Head-Space Techniques. 33: 253-280. 
Laloi D, Bailez O, Blight MM, Roger B, Pham-Delègue MH, Wadhams LJ. 2000. Recognition of Complex Odors by Restrained and Free-Flying Honeybees, Apis Mellifera. Journal of Chemical Ecology 26: 2307-2319.

Le Metayer M, Marion-Poll F, Sandoz J, Pham-Delegue M, Blight M, Wadhams L, Masson C, Woodcock C. 1997. Effect of Conditioning on Discrimination of Oilseed Rape Volatiles by the Honeybee: Use of a Combined Gas ChromatographyProboscis Extension Behavioural Assay. Chemical Senses 22: 391-398.

Lindauer M. 1949. Über Die Einwirkung Von Duft-Und Geschmacksstoffen Sowie Anderer Faktoren Auf Die Tänze der Bienen. Zeitschrift für vergleichende Physiologie 31: 348-412.

Menzel R, Backhaus W, Gouras P. 1991. Vision and Visual Dysfunction. The Perception of Colour.

Menzel R, Müller UJAron. 1996. Learning and Memory in Honeybees: From Behavior to Neural Substrates. 19: 379404.

MENZEL R, Shmida AJBR. 1993. The Ecology of Flower Colours and the Natural Colour Vision of Insect Pollinators: The Israeli Flora as a Study Case. 68: 81-120.

Pelz C, Gerber B, Menzel RJTJoeb. 1997. Odorant Intensity as a Determinant for Olfactory Conditioning in Honeybees: Roles in Discrimination, Overshadowing and Memory Consolidation. 200: 837-847.
Pham-Delegue M, Bailez O, Blight M, Masson C, Picard-Nizou A, Wadhams L. 1993. Behavioural Discrimination of Oilseed Rape Volatiles by the Honeybee Apis Mellifera L. Chemical Senses 18: 483-494.

Raine NE, Chittka LJPO. 2007. The Adaptive Significance of Sensory Bias in a Foraging Context: Floral Colour Preferences in the Bumblebee Bombus Terrestris. 2: e556.

Smith BH. 1993. Merging Mechanism and Adaptation: An Ethological Approach to Learning and Generalization. Insect Learning. Springer, pp: 126-157.

Wadhams L, Blight M, Kerguelen V, Le Métayer M, Marion-Poll F, Masson C, Pham-Delègue M, Woodcock C. 1994. Discrimination of Oilseed Rape Volatiles by Honey Bee: Novel Combined Gas Chromatographic-Electrophysiological Behavioral Assay. Journal of Chemical Ecology 20: 32213231.

Waser NM. 1986. Flower Constancy: Definition, Cause, and Measurement. The American Naturalist, 127: 593-603.

Wenner AM, Wells PH, Johnson DL. 1969. Honey Bee Recruitment to Food Sources: Olfaction or Language? Science 164: 84-86.

Wyszecki G, Stiles WS. 1982. Color Science. Wiley New York. 